九州大学学術情報リポジトリ

Kyushu University Institutional Repository

\title{
TWO NEW SPECIES OF STREPSIPTERA FROM THAILAND (Notulae Strepsipterologicae-V)
}

Kifune, Teiji

Hirashima, Yoshihiro

https://doi.org/10.5109/2391

出版情報 : ESAKIA. 14，pp.61-71，1979-11-15. Entomological Laboratory，Faculty of Agriculture， Kyushu University

バージョン :

権利関係 : 


\title{
TWO NEW SPECIES OF STREPSIPTERA FROM THAILAND (Notulae Strepsipterologicae-V)*
}

\author{
T EiJi Kifune \\ Department of Parasitology, School of Medicine \\ Fukuoka University, Fukuoka 814, Japan \\ and \\ Y OSHIHIRO HIRASHIMA \\ Entomological Laboratory, Faculty of Agriculture \\ Kyushu University,- Fukuoka 812, Japan
}

\begin{abstract}
Two new species of Strepsiptera, Triozocera siamensis and Myrmecolax chantaneeae, are described based on the male specimens collected at light in $\mathrm{San} \mathrm{Pa}$ Tong, northern Thailand. This is the first record of the two genera from Thailand. Keys to the world known species of Triozocera and Myrmecolax are provided.
\end{abstract}

The material on which the present paper is based was collected in the San Pa Tong Rice Experiment Station located about $30 \mathrm{~km}$ south-west of Chiang Mai at light by Mrs. Chantanee Hengsawad, an entomologist working for the station on the population dynamics of the rice hoppers and Elenchus yasumatsui Kifune et Hirashima, which is a stylopid parasitic on the white-backed planthopper and the brown planthopper in northern part of Thailand (Kifune and Hirashima, 1975; Yasumatsu et al., 1975). The material was picked up by Hirashima from her collection of Elenchus yasumatsui while he was visiting the station in 1977 in order to conduct the project "Field studies on the biological control of leafhoppers and planthoppers (Hemiptera : Homoptera) injurious to rice plants in South-East Asia", which was granted by the Ministry of Education, Science and Culture, Tokyo. Thus, this paper is a byproduct of the project.

It is interesting to report here the occurrence of Triozocera and Myrmecolax from Thailand. Although the species of these genera are not associated with

* Contribution from the Entomological Laboratorv, Faculty of Agriculture. Kyushu University, Fukuoka (Ser. 3, No. 63). 
the rice hoppers, Mrs. Chantanee's collection of Strepsiptera is evaluated from a viewpoint of systematics.

It may be noteworthy to mention that the positive phototaxic behavior in Strepsiptera seems to be rather dominant in the primitive groups such as the corioxenid and myrmecolacid species.

\section{CORIOXENIDAE}

\section{Triozocera siamensis, new species}

Male. (Figs. 1-7)

Size. Total length of body 2.1-2.3 mm ; length of head and thorax together 1.3-1. $35 \mathrm{~mm}$; head breadth, 0.52-o. $54 \mathrm{~mm}$; metathoracic sclerites more or less deformed in mounting medium so that no measurement is made; length of aedeagus, $0.39-0.42 \mathrm{~mm}$.

Structure. Typical form of the genus. Head elliptical, broader than long; eyes hemispherical, about 10 facets visible from above ; antennae 7 -segmented, first segment triangular, second segment globular, each flabellum of third and

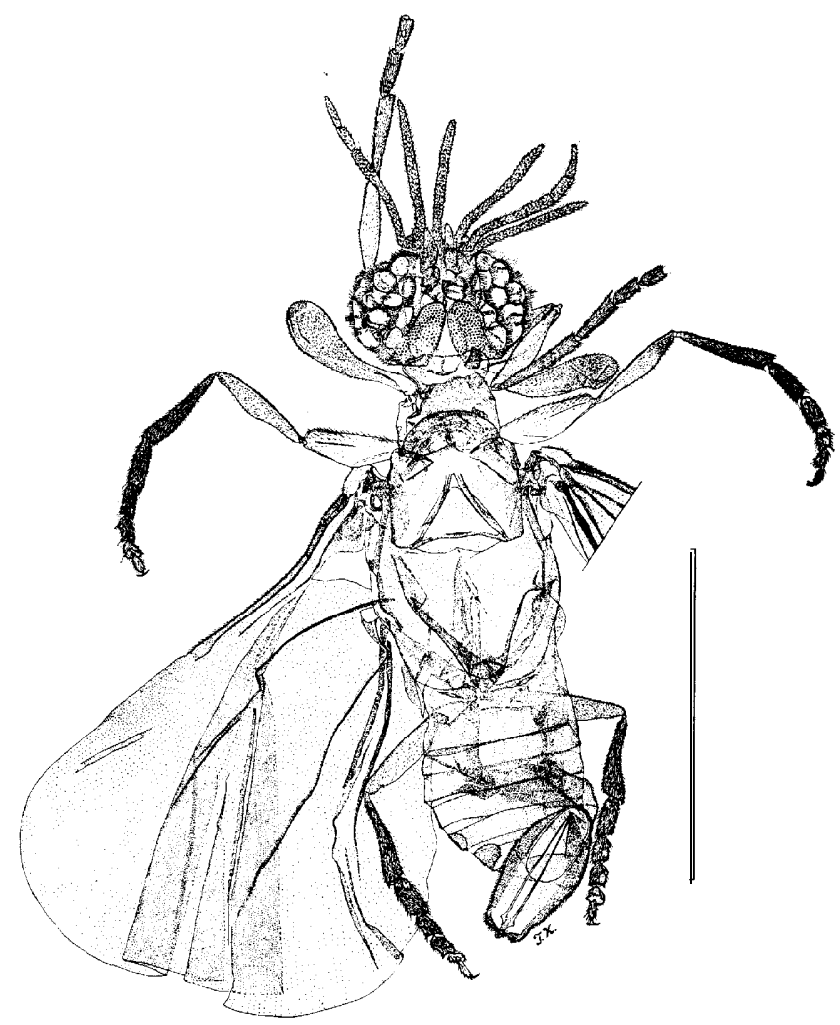

Fig. 1. Triozocera siamensis, new species, holotype male dorsal view. Scale :1 $\mathrm{mm}$. 
fourth segments long, with blunt tips, fifth segment long, cylindrical, slightly broadened toward the distal end, about one and a half times as long as sixth and seventh segments together, seventh segment longer than sixth, flabellum of third segment reaching base of seventh and that of fourth reaching at least basal third of seventh; maxilla Z-segmented, tip of terminal segment fusiform, not surpassing the tip of lanceolate basal segment.

Prothorax half as broad as head; mesothorax a little broader and longer than prot horax ; metathorax as broad as head; anterior margin of prescutum semicircularly convex, external sides of both scuti almost parallel; scutellum equilaterally triangular; postlumbium spindle-shaped, transversely elongated, medianly constricted ; postscutellum subtriangular, tapering backward, almost as long as prescutum and scutellum together.

Abdomen lo-segmented, elliptical in general shape; terminalia elliptical on anterior portion, rectangular on posterior portion ; tenth tergite quadrilateral: aedeagus broadest at basal third and evenly tapering to the tip without any sinuation or constriction.

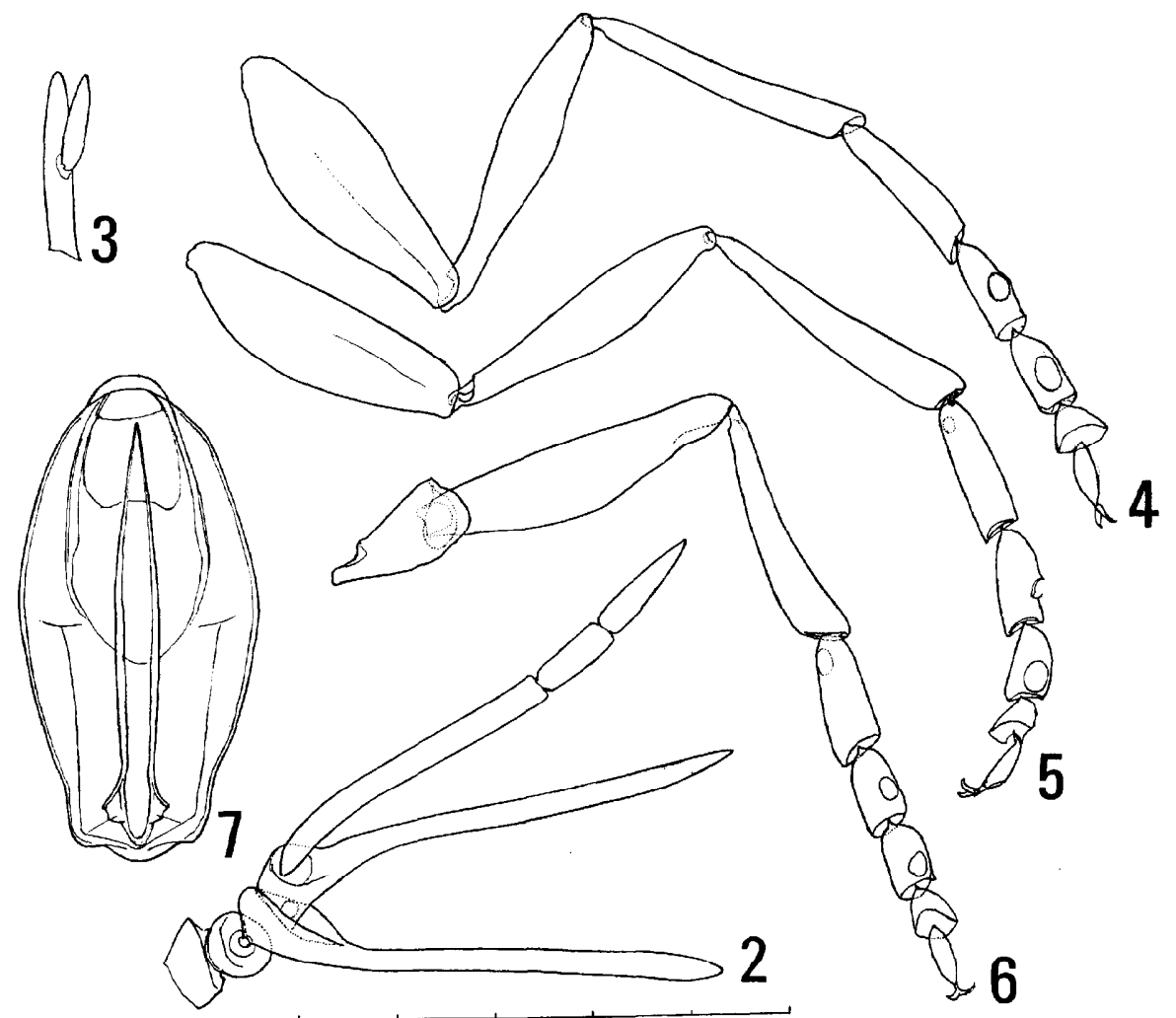

Figs. 2-7. Triozocera siamensis, new species, male. 2: Right antenna. 3: Right maxillary palpus. 4: Right foreleg. 5: Right midleg. 6: Right hindleg. 7: Terminalia. One scale: $0.1 \mathrm{~mm}$. 
Hindwing with typical venation; detached vein to radius short, costa and subcosta reaching midpoint of anterior margin; media, cubitus, and second vannal vein ending more or less apart from wing margin.

Legs slender, of typical form; tarsi 5-segmented, clawed.

Female and triungulin. Unknown.

HCST. Unknown.

Type Materia. : Holotype male (Type No. 2153, Kyushu Univ.), July 23, 1977, and 2 paratopotype males, July 23 and September 17, 1977, collected at light in the San Pa Tong Rice Experiment Station, San Pa Tong, Thailand, by Chantanee Hengsawad. Originally mounted in slides.

TyPe DE?OSITORY: The holotype male and 1 paratopotype male are preserved in the Entomological Laboratory, Faculty of Agriculture, Kyushu University, Fukuoka. Another paratopotype male is deposited in the collection of the San Pa Tong Rice Experiment Station.

Specimens examined other than the type material: 1 male in the same series but not in a good condition. This is also returned to Mrs. Chantanee.

REMARKS: The present new species resembles T.boharti Luna de Carvalho, 1967, from Philippines, but differs from it by the metathorax (especially the scutellum) broad and the aedeagus almost evenly tapering.

Since Pierce (1909) erected the monotypic genus Triozocera (originally spelled as Trioxocera and lately emended by himself) based on $T$. mexicana, the following 13 species including the present new species, which are listed in the key below, have been described from various parts of the world. Two of them, texana Pierce, 1911 from U. S. A. and paulistana Kogan, 1958 from Brazil, were treated as synonym of mexicana by Bohart (1941) and Kinzelbach (1971), respectively. Agreed to Luna de Carvalho (1967), however, we treat texana and paulistana are good species. A key to the world known species of Triozocera is given below.

\section{KEy TO THE WORLD SPECIES (MALES) OF Triozocera}

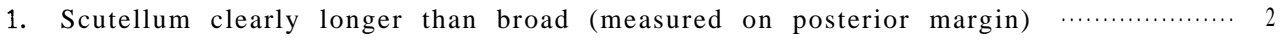

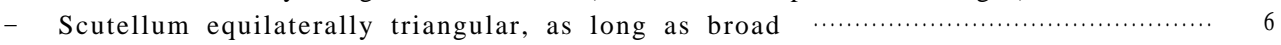

2. Postscutellum at most one-third as broad as long (measured across mid-point) ; aedeagus not constricted, not sinuate in dorsal view; length of body $1.75 \mathrm{~mm}$.

Liberia and ? Nigeria* ...................................... maxi Pox et Pox, 1964

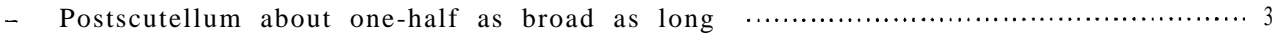

3. Aedeagus tapering evenly to the tip, neither constricted nor sinuate in dorsal

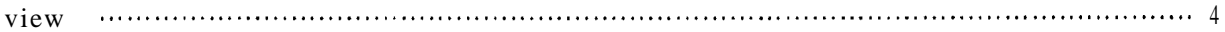

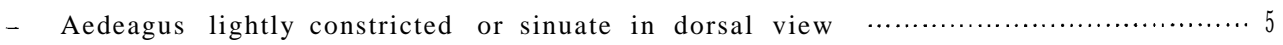

1. Posterior margin of 10 th tergite emarginate in middle ; length of body $2.7 \mathrm{~mm}$.

* Luna de Carvalho (1972) recorded T. maxi from Nigeria. It seems probable that his species is $\mathbf{T}$. dundoana so far as is judged from his figures, especially the shapes of maxilla, 10th tergite and aedeagus. 
Mexico

T. tecpanensis Brailovsky et Márquez, 1974

- Posterior margin of 10th tergite not emarginate ; length of body $3 \mathrm{~mm}$. Brazil

T. paulistana Kogan, 1958

5. Aedeagus lightly constricted, the terminal sixth filamentous; length of body

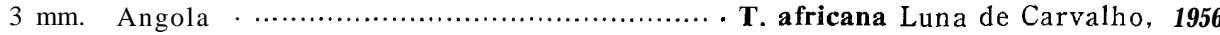

- Aedeagus lightly sinuate in dorsal view, the terminal third tapering to a point, proximal two-thirds nearly parallel-sided; length of body $1.6 \mathrm{~mm}$. Mexico

T. mexicana Pierce, 1909

6. Postscutellum nearly as long as broad; aedeagus strongly constricted near the tip, the terminal sixth arrow-head-like; length of body $4 \mathrm{~mm}$. Angola..

T. gigantea Luna de Carvalho, 1956

Postscutellum longer than broad

7. Detached vein to radius almost inconspicuous; length of body $1.7 \mathrm{~mm}$. Philippines

T. boharti Luna de Carvalho, 1967

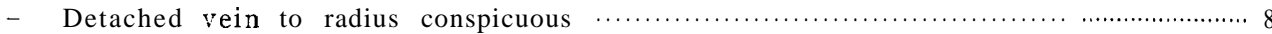

8. Aedeagus not constricted, not sinuate in dorsal view .............................. 9

- Aedeagus lightly sinuate or conspicuously constricted near the tip in dorsal

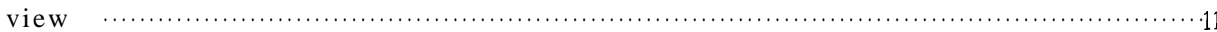

9. Aedeagus broadest at the median portion; tip of distal segment of maxilla not exceeding the prolonged tip of basal segment; length of body 2.1-2.4 mm.

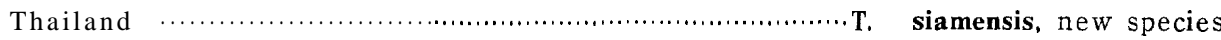

- Aedeagus broadest at the basal portion

10. Second vannal vein almost reaching wing margin; detached vein to media not parallel to it; length of body 2. $25 \mathrm{~mm}$. U. S. A. and Cuba …...T.texana Pierce, 1911

- Second vannal vein ending more or less apart from wing margin; detached vein to media parallel to it; length of body $1.8 \mathrm{~mm}$. New Guinea

T. papuana Kogan et Oliveira, 1964

11. Aedeagus lightly sinuate in dorsal view, evenly tapering to the tip; length of body $3 \mathrm{~mm}$. Japan (Host: Macroscytus japonensis Scott (Cydnidae))

T. macroscyti Esaki et Miyamoto, 1958

- Aedeagus conspicuously constricted near the tip in dorsal view ......................12

12. Epicranial plates approaching posteriorly to each other; jugal vein not so conspicuous ; length of body $2.4 \mathrm{~mm}$. Angola and Nigeria (?)*

T. dundoana Luna de Carvalho, 1956

- Epicranial plates gradually separated posteriorly to each other; jugal vein conspicuous ; length of body $2.8 \mathrm{~mm}$. Ghana …... . endrodyi Luna de Carvalho, 1973

\section{MYRMECOLACIDAE}

\section{Myrmecolax chantaneeae, new species}

Male. (Figs. 8-15)

Size: Total length of body, 2.44-2.55 mm ; length of head and thorax together 1. 52-1. $72 \mathrm{~mm}$; head breadth 0.8-0. $85 \mathrm{~mm}$; metathoracic sclerites more or less deformed in mounting medium so that no measurement is made; length of aedeagus 0.18-0. $21 \mathrm{~mm}$.

Structure: Typical form of the genus. Head transverse, about twice as broad as long, frontal area anteriorly protruded to form an antenna1 base-

* See the footnote on p. 64. 


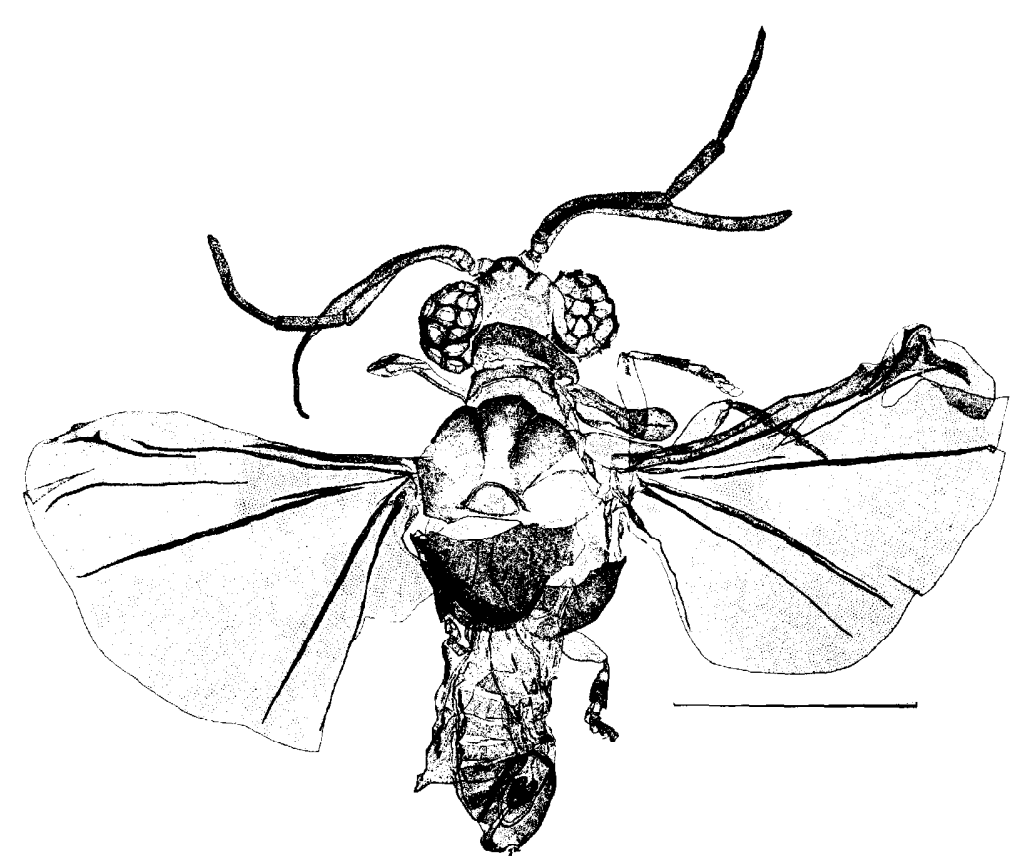

Fig. 8. Myrmecolax chantaneeae, new species, holotype male, dorsal view. Scale: $1 \mathrm{~mm}$.

ment, triangle in form; eyes spherical, about 10 facets visible from above ; antennae 7-segmented, first segment cylindrical, as long as broad, second segment very short, half as long as first, third segment cylindrical with long and flat flabellum almost reaching middle of terminal seventh segment, fourth segment short, as large as second, fifth segment very long, cylindrical, slightly broadened toward the proximal tip, sixth segment about three-fifths as long as seventh, both being flattened; mandibles lanceolate with pointed tip, broadest at proximal third; maxilla Z-segmented, basal segment rectangular, terminal segment cudgel-form, with rounded tip, about four times as long as broad.

Prothorax about two-thirds as long as and less than half as broad as head ; mesothorax almost equal to or slightly narrower than prothorax; metathorax, if not deformed in mounting medium, probably a little narrower than head; anterior margin of prescutum roundly convex, clearly beyond the anterior margins of both scuti; scuti rhomboid, grooves between prescutum and both scuti conspicuous, slightly curved antero-interiorly; scutellum semicircular, narrower than postlumbium ; postlumbium membranous, fusiform ; post . scutellum almost as broad as long, almost as long as prescutum, posterior tip not surpassing the postrior margins of epimera.

Abdomen elliptical or cylindrical in appearance ; terminalia ovoid, posterior half broader than anterior half; tenth tergite cordiform; aedeagus evenly 


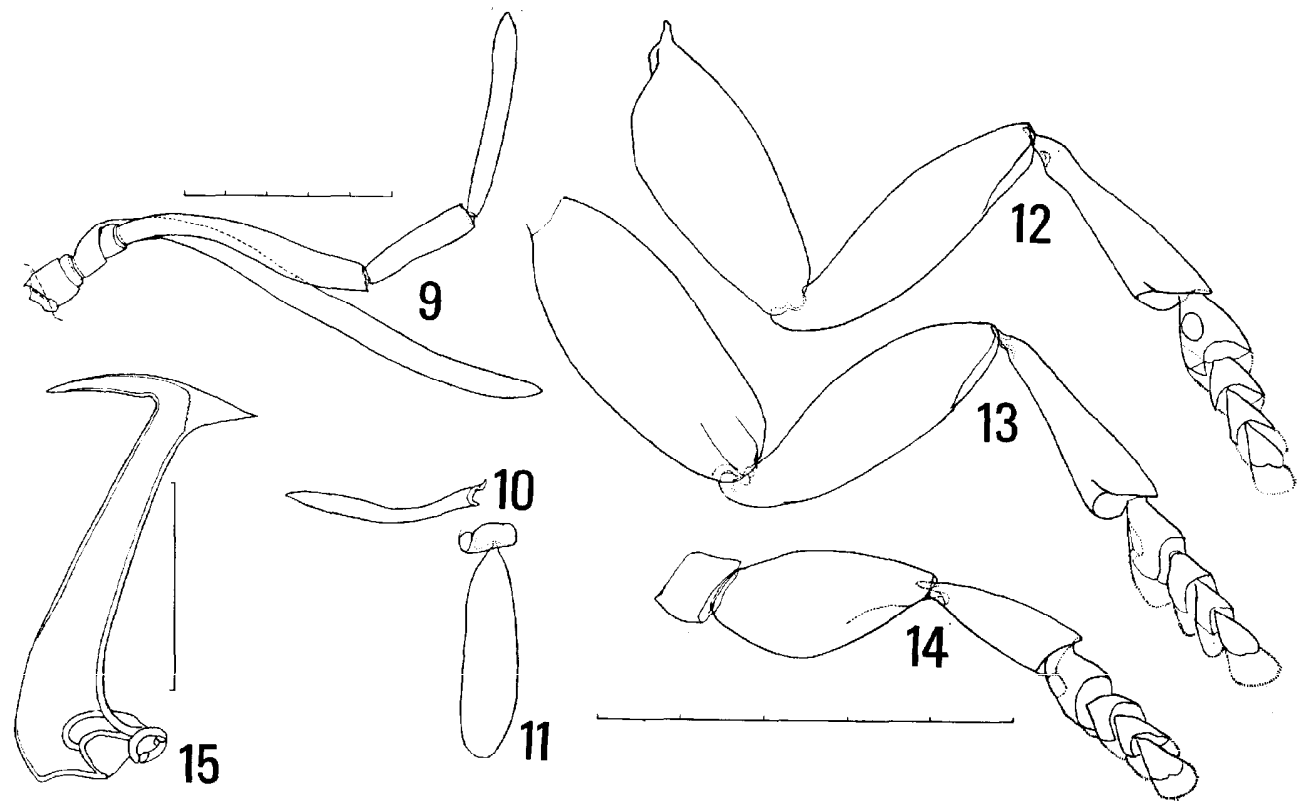

Figs. 9-15. Myrmecolax chantaneeae, new species, male. 9: Right antenna. 10 : Right mandible. 11 : Right maxillary palpus. 12: Right foreleg. 13: Right midleg. 14: Right hindleg. 15: Aedeagus (right lateral view). One scale : $0.1 \mathrm{~mm}$. Fig. 10-14: with same scale.

tapering to apex, dorsal process prominent, sharply pointed ; ventral projection slightly curved.

Hindwing with remarkably bifurcated detached vein to radius, bifurcation sometimes long, its anterior branch environing the distal end of radius, sometimes almost reaching the anterior margin of wing; radius reaching the middle of detached vein ; proximal media half as long as distal media; a single vannal vein almost as long as cubitus; jugal vein very slender, long.

Legs stout, tarsi 4-segmented; hind femur rhomboid, twice as long as broad ; hind coxa trapezoidal.

Female and triungulin. Unknown.

Host. Unknown.

Type material: Holotype male (Type No. 2154, Kyushu Univ.), July 21, 1977, and 3 paratopotype males, July 19, September 17 and 20, 1977, respectively, collected at light by Chantanee Hengsawad in the San Pa Tong Rice Experiment Station, Thailand.

TyPe DePository: Holotype and 1 paratopotype male are preserved in the Entomological Laboratory, Faculty of Agriculture, Kyushu University, Fukuoka. Two paratopotype males are deposited in the San Pa Tong Rice Experiment Station, Thailand. 
Remarks: The present new species is closely allied to $M$. furcatus Bohart, 1951, from Philippines, but differs from it by the detached vein to radius being more closely situated to the wing margin, the slenderer hind femur, and the more sharply protruded dorsal process of the aedeagus.

A key to the world species of Myrmecolax, based on the males, is given below. We recognize 18 species including the present new species. We excluded Caerockolax trinidadensis Giinther, 1949, which was transferred to Myrmecolax by Kinzelbach in 1971, because we are not very certain whether the combination made by him is correct or not so far as we refer to his description. We also excluded Myrmecolax parvus Fox, 1967 because it seems to belong to Lychnocolax Bohart since it possesses the vein $2 \mathrm{~A}$ which is a remarkable character for the latter genus.

$$
\text { Key to the worid species (males) of Myrmecolax }
$$

1. Hindwing with barely distinguishable single detached vein between radius and media; proximal media about one-fourth as long as distal media; length of body $1.7 \mathrm{~mm}$. Liberia M. blickenstaffi Fox, 1967 Hindwing with two detached veins between radius and media; proximal $\mathrm{me}$ dia longer than one-fourth of distal media

2. Distal end of detached vein to radius clearly bifurcated, anterior branch of bifurcation often directed to wing base so as to environ distal end of radius

Distal end of detached vein to radius not bifurcated, or very slightly bifur-

cated, anterior branch of bifurcation very short

3. Flabellum of $3 \mathrm{rd}$ antennal segment reaching middle of 7 th

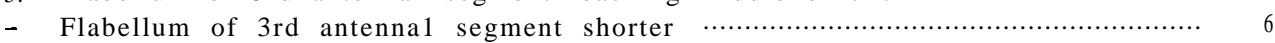

4. Dorsal process of aedeagus short, not conspicuous; distance between internal margins of both eyes as long as diameter of globular eyes. Philippines ......

M. furcatus Bohart, 1951

- Dorsal process of aedeagus long, almost as long as ventral projection …............ 5

5. Ventral projection and body of aedeagus crossing by acute angle; distance between internal margins of both eyes one-third as long as diameter of globular eyes; length of body $2 \mathrm{~mm}$. New Guinea

M. odontognathus Kogan et Oliveira, 1964

- Ventral projection and body of aedeagus crossing by almost right angle ; distance between internal margins of both eyes as long as diameter of globular eyes; length of body $2.44-2.55 \mathrm{~mm}$. Thailand …............ chantaneeae new species

6. Flabellum of 3rd antenna1 segment reaching at most basal third of 7 th; length of body $1.75 \mathrm{~mm}$. Indonesia

M. flagellatus (de Meijere, 1908)

- Flabellum of 3rd antennal segment reaching base of 7 th

7. Aedeagus with pointed dorsal process; length of body $1.65 \mathrm{~mm}$. Argentine ...

M. borgmeieri Hofeneder, 1949

- Aedeagus without dorsal process; length of body 1.3-2.5 mm. Zaire, Angola, Liberia and Ghana …................... M. leleupi Pasteels, 1956 (= M.mano Fox, 1967)

8. Flabellum of $3 \mathrm{rd}$ antennal segment reaching at least middle of 7 th .................. 9

- Flabellum of 3rd antennal segment reaching at most base of 7th ….................... 11

9. Aedeagus without dorsal process. Sri Lanka …............... nietneri Westwood, 1858 
- Aedeagus with prominent dorsal process

10. Distal segment of maxilla about 6 times as long as broad, apex rounded; length of body $2.2 \mathrm{~mm}$. Philippines $\ldots \ldots \ldots \ldots \ldots \ldots \ldots \ldots \ldots \ldots \ldots \ldots \ldots \ldots \ldots \ldots \ldots \ldots \ldots \ldots$. rossi Bohart, 1951

- Distal segment of maxilla about 10 times as long as broad, apex pointed; length of body $1.6 \mathrm{~mm}$. New Guinea ............... Iongipalpis Kogan et Oliveira, 1964

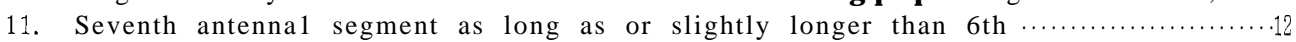

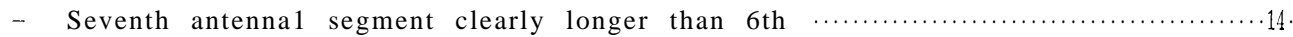

12. Postscutellum short, slightly longer than broad; length of body 2 mm. Philippines ..M. philippinensis Bohart, 1941

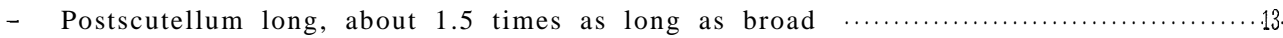

13. Flabellum of 3 rd antennal segment reaching a little beyond base of 7 th; aedeagus curved near base, with clearly pointed dorsal process; detached vein to radius minutely bifurcated. Philippines M. culionensis Bohart, 1951

- Flabellum of 3rd antennal segment reaching middle of 6 th; aedeagus almost straight, without dorsal process; detached vein to radius not bifurcated. Bra-

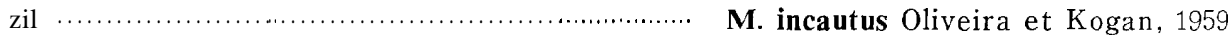

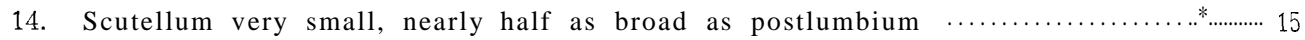

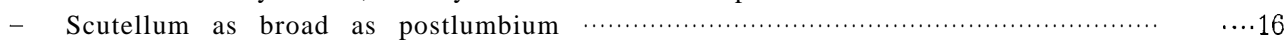

15. Flabellum of 3 rd antennal segment and 5 th broader than 7 th; length of body 1.4-2.4 mm. Zaire, Angola, Nigeria, Ghana, Guinea, and probably Liberia ...

M. congoensis Silvestri, 1939

(= M.lundensis Luna de Carvalho, 1959)

(= M.pseudolundensis Luna de Carvalho, 1959)

(= M. afurcifer Luna de Carvalho, 1959)

$(?=$ Afrostylops lunai Fox et Fox, 1964)

- Flabellum of 3rd antenna1 segment and 5 th as broad as 7 th; length of body

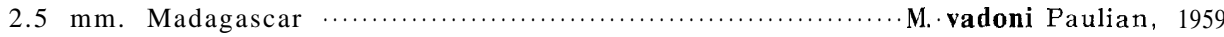

16. Aedeagus slender, nearly parallel-sided or slightly tapering; tip of prescutum reaching beyond anterior margins of scuti; length of body $1.4 \mathrm{~mm}$. Liberia M. liberiensis Fox, 1967

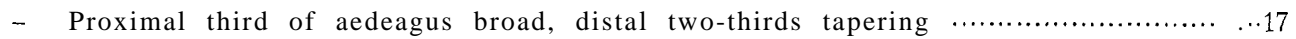

17. Distal half of aedeagus strongly curved dorsally in lateral view ; trp of prescuturn not beyond anterior margins of scuti; hind femur with broadened apex;

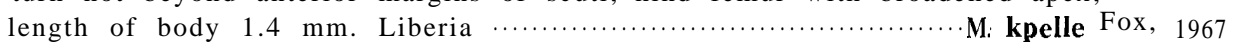

- Aedeagus almost straight in lateral view; tip of prescutum beyond anterior margins of scuti; hind femur slender, not expanded apically; length of body

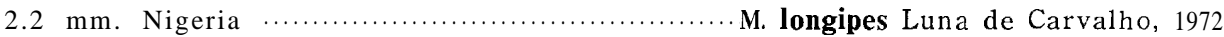

\section{Acknowledgements}

We are much indebted to Mrs. Chantanee Hengsawad, San Pa Tong Rice Experiment Station, Thailand, for the valuable specimens. Thanks are also due to the Ministry of Education, Science and Culture, Tokyo, for the support of the project "Field studies on the biological control of leafhoppers and planthoppers (Hemiptera: Homoptera) injurious to rice plants in South-East Asia" as one of the Overseas Scientific Surveys. 


\section{References}

Bohart, R. M. 1941. A revision of the Strepsiptera with special reference to the species of North Amerıca. Univ. Calif. Publ. Ent. 7: 91-169, pl. 3.

- 1951. The Myrmecolacidae of the Philippines (Strepsiptera). Wasmann J. Biol. 9 : 83-103, pls. 1-4.

Brailovsky A. H.. \& C. Márquez M. 1974. Una nueva especiemexicana de Triozocera Pierce (Strepsiptera, Mengeidae). An. Inst.Biol., Univ. Nac.autón.Méx. 45 (ser. Zool.): 105-110, 4 figs.

Esaki, T., \& S. Miyamoto. 1958. The Strepsiptera parasitic on Heteroptera. Proc. 10th int. Congr. Ent. 1: 373-381, 25 figs.

Fox, J. W. 1967. Liberian Strepsiptera in the Smithsonian collection with descriptions of seven new Myrmecolacidae. Proc.U. S. Natl. Mus. 124 (3625) : 1-14, 51 figs.

__ \& R. M. Fox. 1964. A new species of Triozocera (Mengeidae : Strepsiptera) from Liberia, West Africa. Ann. ent. Soc. Amer. 57: 402-405, 1 fig.

- \&- 1964 a. A new genus and species of Stylopidae (Strepsiptera) from Liberia, West Africa. Ibid. 57: 754-756, 2 figs.

Hofeneder, K. 1949-50. U̇ber einige Strepsipteren. Brotéria 18: 109-122, 145-166; 19: 8096, 35 figs.

Johnson, V. 1973. The female and host of Triozocera mexicana (Strepsiptera: Mengeidae), Ann. ent.Soc. Amer. 66: 671-672, 4 figs.

Kifune, T., \& Y. Hirashima. 1975. A new species of the genus Elenchus from Thailand (Strepsiptera : Elenchidae) (Notulae Strepsipterologicae-II). Mushi, Fukuoka 48: 145148, 2 pls.

Kinzelbach, R. K. 1970. Loania canadensis n. gen. n. sp. und die Untergliederung der Callipharixenidae. Senckenberg. biol. 51: 99-107, 7 Abb.

- 1971. Morphologische Befunde der Fächerflüglern und ihre phylogenetische Bedeutung (Insecta: Strepsiptera). Zoologica (119) : 1-256, 182 Abb.

Kogan, M. 1958. A new species of the genus Triozocera Pierce from Brazil (Mengeidae, Strepsiptera). Studia ent. 1: 421-426, 9 figs.

- \& S. J. de Oliveira. 1964. New Guinean Mengeidae and Myrmecolacidae of the American Museum of Natural History (Strepsiptera). Ibid. 7: 459-470, 51 figs.

Luna de Carvalho, E. 1956. Primeira contribuiçãopara o estudo dos Estrepsipteros angolenses (Insecta Strepsiptera). Publ. cult. Co. Diam. Angola (29) : 11-54, 37 figs.

- 1959. Segunda contribuição para o estudo dos Estrepsipteros angolenses (Insecta Strepsiptera). Ibid. (41) : 125-154, 20 figs.

_- 1967. Terceira contribuição para o estudo dos Estrepsipteros angolenses (Insecta Strepsiptera). Ibid. (77) : 13-56, 24 figs.

— 1972. Premiere contribution à l'étude des Strepsiptères de la Nigeria (Insecta, Strepsiptera). Ent. Soc. Nigeria occas. Publ. (9) : 19-55, 121 figs.

— 1973. Entomological exploration in Ghana by Dr. S. Endrödy-Younga. 17. Strepsiptera. Folia ent. Hung. (ser. nov.) 26 (supp1.) : 19-55, 121 figs.

Meijere, J. C. H. de. 1908. Zwei neue Strepsipteren aus Java. Tijd. Ent. 51: 185-190, Taf. 6.

- 1911. Bemerkungen zu den javanischen Strepsipteren Parastylops flagellatus de Meij. und Halictophagus jacobsoni de Meij. Ibid. 54: 255-257, 1 fig.

Oliveira, S. J. de, \& M. Kogan. 1959. Contribution to the knowledge of the Brazilian Strepsiptera (Insecta). Mem. Inst. Oswaldo Cruz 57: 219-233, 34 figs.

__ \& 1963. A new species of Pseudoxenos Saunders, 1872, and a new record of Myrmecolax incautus Oliveira \& Kogan, 1959 (Strepsiptera, Insecta). Ibid. 61: 351-356, 16 figs.

Pasteels, J. 1956. Enquêtes sur les Strepsipteres (5 série). Bull. Ann. Soc. R. Ent.Belg. 
92: 109-119, 36 figs.

Paulian. R. 1959. Recherches sur les insectes d'importance biologique à Madagascar (XXIX àXXXIII). Mem.Inst. sci. Madagascar, sér. E, 11: 1-16, 7 figs.

Pierce, W. D. 1909. A monographic revision of the twisted winged insects comprising the order Strepsiptera Kirby. Bull. U. S. Natl.Mus. (66) : I-XII, 1-232, 15 pls., 3 figs., 1 map.

1911. Strepsiptera. In : Wytsman, P. (ed.) : Gen. Insect. (121) : 1-56, 5 pls.

- 1911 a. Notes on insects of the order Strepsiptera, with descriptions of new species. Proc.U.S. Natl. Mus. 40: 487-511.

-1918. The comparative morphology of the order Strepsiptera together with records and descriptions of insects. Ibid. 54: 391-501, pls. 64-78, 5 figs., 1 map.

Silvestri, F. 1939. Strepsipterorum species nova ex Congo Belgico. Bull. Mus. Hist. nat. Belg. 15 (8): 1-4, 2 fige.

Yasumatsu, K., T. Wongsiri, S. Navavichit \& C. Tirawat. 1975. Approaches toward an integrated control of rice pests. Part 1: Survey of natural enemies of important rice pests in Thailand. Plant Prot. Serv. Tech. Bull. (24) : 1-21. Dept. Agr., Thai Ministry of Agr. and Co-operatives, and UNDP 9/FAO THA 68/526. 